\title{
Analisis Industri Rumah Tangga Kerupuk Ikan dan Kontribusinya terhadap Pendapatan Keluarga di Kelurahan Jelmu Kota Jambi
}

\author{
${ }^{1}$ Wiyan Mailindra, ${ }^{2}$ Muhammad Amali \\ ${ }^{1}$ STIE GK Muara Bulian \\ ${ }^{2}$ Fakultas Ekonomi, Universitas Batanghari Jambi, Indonesia \\ Correspondence email: wiyanmailindra180@gmail.com, m.amali278791@gmail.com
}

\begin{abstract}
The aim of this study is the first to know the characteristics of industrial workers' households in the village of fish crackers jelmu jambi city views from sex, age, education level, the number of dependents, employment status, duration of operations and the initial capital. Secondly to study and analyze the amount of household income of industrial workers in the village of fish crackers jelmu jambi city. Third to know how much revenue contribution of household industry workers fish crackers on family income in Sub Jelmu. From the discussion we know that the characteristics of the respondents viewed the sex, most craftsmen female fish crackers or equal to 80 percent of 15 respondents. Then in terms of age craftsmen fish crackers between 40-49 years of age or 46.67 percent of the 15 people total respondents. Viewed from the level of education in the village of fish crackers pengarjin jelmu most educated junior or 46.67 percent. Number of dependents of each of the respondents ranged between 1-6 people. Among 10 respondents, or 66.67 per cent with two-3orang family members only. From satatus jobs, most of the respondents made this fish crackers craft business as a major work that is equal to 73.33 percent. Old businesses ranging from 10-30 years. Judging from the initial capital issued by the craftsmen of fish crackers ranging from Rp. 350,000 - 699,000 totaling 10 respondents or 66.67 percent of total respondents. Of the total employment of each worker is different, ranging from 1-4 people. In terms of revenue ranging from Rp. 1,500,000 - 2,000,000.- per month. Acceptance is not reduced sales of capital and production costs. Then the family income of the highest fish crackers craftsmen USD 1.225 million per month. And lowest income of Rp. 665,000.- per month. Meanwhile, cracker craftsmen revenue contribution of fish to the family income amounted to 71.72 percent. With average family income of $\pm R p$. 926,266.67.- per month. And the average income of farmers amounted to \pm Rp fish crackers. 630,266.67.- per month.
\end{abstract}

Keyword : industry, village

\section{PENDAHULUAN}

Perkembangan industri kota Jambi cukup meningkat hal ini dapat di lihat dari penambahan unit usaha perusahaan (formal dan non-formal) baru sebagai implikasi dan sosialisasi Perda Kota Jambi Nomor 10 tahun 2002 tentang izin industri, usaha perdagangan dan tanda daftar gudang dan pembinaan secara tepat. Dengan adanya penambahan usaha baru, maka secara otomatis berdampak positif pula terhadap penyerapan tenaga kerja, investasi dan nilai produksi atau jasa yang di hasilkan dan juga terhadap tingkat pendapatan. Berdasarkan data dari Dinas Deperindag Kota dan Kabupaten diketahui perkembangan industri kecil di Propinsi Jambi tahun 1999 - 2017 menunjukan perkembangan yang cukup mengembirakan. Dimana pada tahun 1999 terdapat 10.958 unit usaha meningkat menjadi 13.064 unit usaha pada tahun 2002, sedangkan tenaga kerja juga meningkat dari 35.165 orang menjadi 44.257 orang, investasi meningkat dari Rp. 39.886,645 juta menjadi Rp. 44.793,163 juta dan nilai produksi meningkat dari Rp. 87.450 juta menjadi Rp. 108.200 juta.

Tahun 2003 masih terjadi peningkatan dimana jumlah unit usaha meningkat dari 13.673 unit usaha menjadi 13.863 unit usaha pada tahun 2004, sedangkan tenaga kerja meningkat dari 44.578 orang menjadi 44.617 orang, investasi meningkat dari RP. 47.015, 678 juta menjadi Rp. 48.254,341 juta dan nilai produksi juga meningkat dari Rp. 163.324 Juta menjadi Rp. 166.584,324 juta begitu juga sampai akhir 2006 subsektor industri kecil masih menunjukan peningkatan dimana jumlah unit usah meningkat dari tahun sebelumnya yakni tahun 2005 sebanyak 14.245 menjadi 15.245 unit usaha, tenaga kerja dari 44.617 orang menjadi 44.695 orang, sedangkan untuk investasi meningkat dari Rp. 49.493,010 juta menjadi Rp. $50.731,679$ juta dan nilai produksi juga meningkat dari Rp.166.844,656 juta menjadi Rp. 167.104,984 juta.

Berdasarkan kondisi diatas maka sektor industri diharapkan mempunyai arti penting dalam memegang peranan pembangunan ekonomi di Kota Jambi khususnya Kelurahan Jelmu. Hal ini disebabkan 
oleh karna industri harus mampu menjadi pengerak bagi pertumbuhan ekonomi lainya. Dengan peranannya dalam ekonomi seimbang dan kokoh antara sektor industri dan sektor pertanian yang tangguh (Anonim, 2001). Kelurahan Jelmu Kecamatan Pelayangan terdapat industri-industri kecil berupa kerajinan kayu, industri batik, industri makanan dan lain- lain. Perkembangannya industri tersebut telah membentuk sentrasentra industri kecil salah satunya adalah industri rumah tangga kerupuk ikan. Penyetaraan industi kecil dengan industri besar juga diambil dari dampak keberadaannya yaitu berdampak positif terhadap upaya keterbatasan lapangan kerja dan menambah pendapatan masyarakat. Perkembangan industri tidak terlepas dari beberapa faktor yang mempengaruhinya yaitu bahan baku yang mudah didapat, modal yang berasal dari modal sendiri (modal kelompok) serta tenaga kerja yang dibutuhkan cukup tersedia serta teknologi yang di gunakan. Tentu saja faktorfaktor tersebut akan saling mendukung bagi peningkatan produksi industri rumah tangga kerupuk ikan selanjutnya. (Adisetiawan, 2013)

Dengan demikian akan menciptakan nilai tambah yang pada giliranya akan dapat menyerap tenaga kerja yang lebih banyak dan akan menaikan pendapatan pada sektor ini. Dengan didukung bahan baku yang cukup tersedia dengan baik, potensi yang bagus dan pemasaran yang mudah dilakukan. dengan adanya pertambahan jumlah produksi, investasi atau penanaman modal dan pendapatan ini secara terus menerus diharapkan akan tercipta keuntungan yang lebih besar dan bisa di investasikan kembali sehingga akan menciptakan lapangan kerja yang lebih banyak. Dan ini menunjukan industri kerupuk ikan cukup bisa di andalkan untuk memberikan kontribusinya yang cukup besar terhadap pendapatan keluarga. (Adisetiawan dan Hasminidiarty, 2011)

\section{METODE PENELITIAN}

Melakukan penggolongan data yang relevan terhadap masalah yang dibahas dilakukan dengan menggunakan cross tabulation atau juga dikenal dengan tabulasi silang yaitu suatu bentuk tabel yang mengambarkan hubungan secara deskriptif dari dua variabel atau lebih. Pengolahan data dilakukan secara selektif dan di sesuaikan dengan masalah yang akan dibahas, penggolongan data dilakukan dengan mengunakan analisis yaitu tabel frekuensi dan tabulasi silang untuk variabel-variabel tertentu. Untuk mengetahui besarnya pendapatan usaha pengrajin industri rumah tangga kerupuk ikan perbulanya dilakukan dengan cara sebagai berikut: (Adisetiawan, 2012)

a. Pendapatan Kotor

TR=P.Q

Keterangan: TR = Total revenue; $\mathrm{P}=$ harga kerupuk ikan; $\mathrm{Q}=$ Kualitas/jumlah kerupuk ikan.

b. Pendapatan bersih

$\mathrm{Y}=\mathrm{TR}-\mathrm{TC}$

Keterangan: $\mathrm{Y}=$ Pendapatan; $\mathrm{TR}=$ Total Penerimaan; $\mathrm{TC}=$ Biaya Total

Untuk mengetahui besarnya kontribusi pendapatan usaha perbulan pengrajin industri rumah tangga di Kelurahan Jelmu terhadap pendapatan keluarga di gunakan rumus:

$K P S=\frac{P P S}{P R T} \times 100$

Keterangan: KPS = Kontribusi pendapatan usaha perbulan pengajin industri rumah tangga kerupuk ikan terhadap pendapatan keluarga; PPS = Pendapatan pekerja industri kerupuk ikan perbulan; PRT = Pendapatan rumah tangga perbulan

\section{HASIL DAN PEMBAHASAN}

Karakteristik responden atau identitas responden merupakan latar belakang keadaan responden yang turut mempengaruhi pola pikir dan perilaku pengusaha dalam menentukan langkah-langkah atau tindakan yang akan ditempuh dalam rangkaian mencapai tujuan yang diinginkan. Dengan diketahuinya latar belakang pengusaha industri kerupuk ikan yang dilihat dalam penelitian ini adalah sebagai berikut :

\section{Responden Menurut Jenis Kelamin}


Karakteristik responden menurut jenis kelamin merupakan Salah satu alat untuk mengetahui apakah pengrajin kerupuk ikan di Kelurahan Jelmu ini lebih di dominasi kaum perempuan atau laki-laki. Untuk mengetahui lebih jelasnya dapat kita ketahui pada tabel berikut ini :

Tabel 1

Jumlah dan Persentase Responden Menurut Jenis Kelamin

\begin{tabular}{lrrr}
\hline \multicolumn{1}{c}{ Jenis kelamin } & Jumlah (orang) & Persentase (\%) & 20 \\
\hline Laki-laki & 3 & 80 \\
Perempuan & 12 & $\mathbf{1 0 0}$ \\
Total & $\mathbf{1 5}$ & & \\
\hline
\end{tabular}

Sumber : data olahan

Berdasarkan penelitian terhadap 15 orang responden pengerajin kerupuk ikan di Kelurahan Jelmu Kecamatan Pelayangan Kota Jambi, di ketahui bahwa sebagian besar berjenis kelamin perempuan yaitu berjumlah 12 orang atau 80 persen. Sedangkan yang berjenis kelamin laki-laki hanya berjumlah 3 orang saja. Hal ini di sebabkan karna tingkat ketelitian dan keterampilan perempuan dalam hal kerajinan membuat kerupuk ikan yang lebih tinggi dari laki-laki, sehingga hanya ada beberapa orang saja responden pengrajin kerupuk ikan yang berjenis kelamin laki-laki.

\section{Responden Menurut Kelompok Umur}

Umur yang di maksud dalam penelitian ini adalah usia dari pengusaha industri kerupuk ikan yang berlokasi di Kelurahan Jelmu Kecamatan Pelayangan. Berikut ini di sajikan gambaran mengenai pengusaha kerupuk ikan di Kelurahan Jelmu berdasarkan Umur sebagai berikut :

Tabel 2

Jumlah dan Persentase Responden Menurut Kelompok Umur

\begin{tabular}{lrr}
\hline \multicolumn{1}{c}{ Kelompok Umur } & Jumlah (orang) & Persentase (\%) \\
\hline $28-32$ & 1 & 6,67 \\
$33-37$ & 3 & 20 \\
$38-42$ & 5 & 33,33 \\
$43-47$ & 3 & 20 \\
$48-52$ & 2 & 13,33 \\
$53-57$ & 1 & 6,67 \\
Total & $\mathbf{1 5}$ orang & $\mathbf{1 0 0}$ \\
Rata-rata Umur & & $\mathbf{4 2}$ Tahun \\
\hline
\end{tabular}

Sumber : Diolah dari data primer

Tabel 2 diatas, dapat diketahui bahwa umur pengusaha kerupuk ikan di Kelurahan Jelmu Kecamatan Pelayangan berkisar antara 28-57 tahun. Masing-masing dapat dilihat sebagian besar yaitu antara 38-42 tahun atau sebesar 33,33 persen atau lima orang pengusaha sedangkan yang berumur 28-32 tahun hanya satu orang pengusaha atau sebesar 6,67 persen, kemudaian sebanyak 20 persen pengusaha berumur antara 33-37 tahun dan pengusaha kerupuk ikan dengan umur 43-47 tahun juga sebanyak 20 persen, sedangkan umur pengusaha 48-52 tahun hanya sebanyak dua orang pengusaha. Serta yang berumur antara 53-57 tahun hanya satu orang pengusaha kerupuk ikan atau sebesar 6,67 persen. Dari keterangan tersebut dapat disimpulkan bahwa rata-rata umur pengusaha kerupuk ikan di Kelurahan Jelmu Kota Jambi adalah 42 tahun.

\section{Responden Menurut Tingkat Pendidikan}

Tingkat pendidikan pengusaha yang dilihat dalam penelitian ini adalah pendidikan formal tertinggi yang ditamatkan atau diselesaikan oleh pengrajin kerupuk ikan di Kelurahan Jelmu Kecamatan Pelayangan Kota Jambi. dapat dilihat pada tabel berikut : 
Tabel 3

Jumlah dan Persentase Responden Menurut Tingkat Pendidikan

\begin{tabular}{|c|c|c|c|}
\hline No & Pendidikan & Jumlah (orang) & Persentase (\%) \\
\hline 1. & SD/Sederajat & 3 orang & 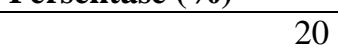 \\
\hline 2. & SMP/Sederajat & 7 orang & 46,67 \\
\hline 3. & SMA/Sederajat & 5 orang & 33,33 \\
\hline Total & & 15 orang & 100 \\
\hline
\end{tabular}

Sumber : data olahan

Tabel 3 diatas, diketahui bahwa sebagian besar tingkat pendidikan Pengrajin industri kerupuk ikan di Kelurahan Jelmu berpendidikan SMP/Sederajat sebanyak 7 orang atau 46,67 persen, dan tamatan SMA/Sederajat sebanyak 5 orang atau 33,33 persen kemudian yang berpendidikan sekolah dasar atau SD sebanyak 3 orang atau 20 persen dari total responden. Dari tabel diatas dapat kita simpulkan bahwa pendidikan para pengusaha atau pengrajin kerupuk ikan di Kelurahan Jelmu Kecamatan Pelayangan masih tergolong rendah karna sebanyak 46,67 persen masih berpendiddikan SMP.

\section{Responden Menurut Jumlah Tanggungan Keluarga}

Secara teoritis, jumlah dari suatu keluarga akan mempengaruhi hasrat atau kemampuan untuk berusaha. Semakin besar jumlah keluarga maka semakin besar pula beban tanggungan yang harus dipikul oleh kepala keluarga, terutama dalam memenuhi kebutuhan hidup sehari-hari. Untuk mengetahui jumlah tanggungan dari responden kita perhatikan tabel berikut ini.

Tabel 4

Jumlah dan Persentase Responden Menurut Jumlah Tanggungan Keluarga

\begin{tabular}{lrrr}
\hline Beban Tanggungan Keluarga & Jumlah (orang) & Persentase (\%) \\
\hline & $0-1$ & 3 orang & 20 \\
& $2-3$ & 10 orang & 66,67 \\
& $4-5$ & 1 orang & 6,67 \\
Total & $>6$ & 1 orang & 6,67 \\
Rara-rata tanggungan & & $\mathbf{1 5}$ orang & $\mathbf{1 0 0 , 0 0}$ \\
\hline
\end{tabular}

Sumber : data olahan

Tabel 4 diatas dapat dijelaskan bahwa beban tanggungan keluarga responden 2 - 3 orang merupakan yang terbanyak yaitu sebanyak 10 orang atau 66,67 persen. Berikutnya adalah responden yang memiliki beban tanggungan $0-1$ orang berjumlah 3 orang atau 20 persen. Kemudian diikuti oleh responden yang memiliki beban tanggungan 4 - 5 sebanyak 1 orang 6,67 persen. Kemudian untuk umur > 6 orang yaitu berjumlah 1 orang atau 6,67 persen dari jumlah responden, keterangan tersebut dapat disimpulkan bahwa rata-rata jumlah anggota keluarga pengrajin industri kerupuk ikan di Kelurahan Jelmu Kecamatan Pelayangan yaitu 2 orang.

\section{Responden Berdasarkan Status Pekerjaan}

Pada bagian ini akan dijelaskan mengenai status pekerjaan dari seorang pengrajin kerupuk ikan di Kelurahan Jelmu. Status pekerjaan yang dimaksudkan dalam penelitian ini adalah apakah pekerjaan sebagai pengerajin kerupuk tersebut merupakan pekerjaan utama atau sampingan. Dapat di lihat pada tabel berikut ini :

Tabel 5

Jumlah dan Persentase Pengrajin Menurut Status Pekerjaan

\begin{tabular}{llrrr}
\hline \multicolumn{1}{c}{ No } & \multicolumn{1}{c}{ Status Pekerjaan } & Jumlah & \multicolumn{2}{c}{ Persentase } \\
\hline 1. & Pekerjaan utama & & 11 & 73,33 \\
2. & Pekerjaan sampingan & 4 & 26,67 \\
Total & & $\mathbf{1 5}$ & $\mathbf{1 0 0 , 0 0}$ \\
\hline
\end{tabular}

Sumber : data olahan 
Berdasarkan Tabel 5. diatas, maka dapat diketahui bahwa sebagian besar pengusaha kerupuk ikan menjadikan usaha industri kerupuk ikan sebagai pekerjaan utama. Hal ini dapat dilihat dari banyaknya jumlah pengusaha kerupuk ikan dengan status pekerjaan adalah sebagai pekerjaan utama yaitu sebanyak 11 orang atau sebanyak 73,33 persen. Sedangkan pengusaha kerupuk ikan dengan status pekerjaan sampingan tercatat sebanyak 4 orang atau 26,67 persen. Pengusaha kerupuk ikan dengan status pekerjaan sampingan ini cukup beragam diantaranya adalaha sebagai Pegawai Negri Sipil (PNS), pengusaha batik, penjual kue serta wiraswata atau dagang. Begitu juga dengan pekerjaan keluarganya yang lain ada yang bekerja sebagai pedagang, Pegawai Negri, serta berwiraswasta. Dari tabel diatas dapat kita simpulkan bahwa rata-rata pengusaha kerupuk ikan ini menjadikan pekerjaan ini sebagai pekerjaan utama atau 73,33 persen.

\section{Responden Menurut Lama Berusaha}

Pada bagian ini akan di jelaskan mengenai lamanya responden telah bekerja sebagai pengusaha kerupuk ikan di Kelurahan Jelmu Kecamatan Pelayangan Kota Jambi. Lama usaha merupakan lamanya waktu (tahun) yang telah dilalui pengusaha kerupuk ikan di Kelurahan Jelmu Kota Jambi dalam menjalankan usahanya sebagai pengusaha kerupuk ikan. Berikut ini dijelaskan gambaran mengenai pengusaha kerupuk ikan di Kelurahan Jelmu berdasarkan lamanya usaha sebagai berikut :

\section{Tabel 6}

Jumlah Responden Menurut Lama Berusaha (Tahun)

\begin{tabular}{rrrr}
\hline \multicolumn{1}{r}{ Lama Berusaha (Tahun) } & Jumlah (orang) & Persentase (\%) \\
\hline $2-9$ & & 7 & 46,67 \\
$10-17$ & 1 & 6,67 \\
$18-25$ & 5 & 33,33 \\
$26-33$ & 1 & 6,67 \\
& & 1 & 6,67 \\
Total & & $\mathbf{1 5}$ & $\mathbf{1 0 0}$ \\
Rata-rata Lama Usaha & & $\mathbf{1 5}$ Tahun \\
\hline
\end{tabular}

Sumber : data olahan

Tabel 6 diatas, dapat di jelaskan bahwa lama usaha industri kerupuk ikan di Kelurahan Jelmu ini berkisar antara 1-40 tahun. Dari sebanyak 15 orang responden terdapat sebanyak 7 orang responden atau 46,67 persen telah menekunin usaha sebagai pengusaha kerupuk ikan yaitu 2-9 tahun. Sedangkan pengusaha yang telah bekerja selama 18-25 tahun sebanyak 5 orang pengusaha atau sebesar 33,33 persen. Sedangkan dengan lama usaha 1-4 tahun sebanyak 1 orang pengusaha, kemudian dengan lama usaha 10-17 tahun juga sebanyak 1 orang pengusaha atau 6,67 persen, kemudian dengan lama usaha 26-33 tahun, dan 33-41 tahun masing-masing sebanyak satu orang pengusaha atau dengan persentase 6,67 persen. Dari keterangan tersebut dapat dilihat bahwa rata-rata pengalaman usaha pengrajin atau pengusaha kerupuk ikan di Kelurahan Jelmu adalah 15 tahun.

\section{Responden Menurut Jumlah Modal Awal}

Untuk dapat memulai usaha, modal awal merupakan utama yang harus dipenuhi, tanpa adanya modal awal maka usaha tersebut tidak akan berjalan dengan baik. Begitu juga hal untuk memenuhi usaha industri kerupuk ikan. Modal awal yang digunakan oleh pengerajin kerupuk ikan berasal dari modal sendiri. Modal awal tersebut digunakan untuk membeli peralatan dan perlengkapan memasak seperti panci, tungku, baskom, papan lindasan, serta ikan yang merupakan bahan utama dan lain sebagainya. Untuk mengetahui lebih rinci modal awal yang digunakan oleh reesponden dapat dilihat pada tabel berikut :

Tabel 7

\section{Responden Menurut Jumlah Modal Awal Yang Digunakan (Rupiah)}

\begin{tabular}{lccc}
\hline Modal Awal (Rp) & Jumlah (orang) & Persentase (\%) & 33,33 \\
\hline $350.000-480.000$ & 5 & 13,33 \\
$481.000-611.000$ & 2 & 26,67 \\
$612.000-742.000$ & 4 & 28
\end{tabular}

Analisis Industri Rumah Tangga Kerupuk Ikan dan Kontribusinya terhadap Pendapatan Keluarga di Kelurahan Jelmu Kota Jambi 
$743.000-873.000$

$874.000-1.040 .000$

Jumlah
2

2

15

Rata-rata modal awal
13,33

13,33

100

617.200

Sumber : data olahan

Tabel 7 diatas, dapat dijelaskan bahwa responden yang menggunakan modal awal berkisar antara Rp.350.000 - 480.000 yaitu sebanyak 5 orang atau 33,33 persen. Kemudian untuk responden yang menggunakan modal awal berkisar antara Rp.481.000 - 611.000 berjumlah 2 orang atau 13,33 persen. Dan dengan pendapatan Rp. 612.000 - 742.000 sebanyak 4 orang atau 26,67 persen. Sedangkan Dengan modal awal Rp. 743.000 - 873.000 dan Rp. 874.000 - 1.040 .000 dengan jumlah responden masing-masing sebanyak 2 orang atau 13,33 persen. Dari tabel diatas dapat disimpulkan rata-rata modal awal pengusaha kerupuk ikan di kelurahan jelmu kota jambi yaitu sebesar Rp. 617.200.-

\section{Responden Menurut Jumlah Tenaga Kerja}

Kegiatan produksi, tenaga kerja sangat dibutuhkan karena tanpa tenaga kerja kegiatan produksi tidak dapat dilakukan, sehingga keberadaan tenaga kerja tidak dapat dihilangkan. Penyerapan tenaga kerja pada industri kerupuk ikan sangat membantu masyarakat karena industri ini mampu menyerap tenaga kerja yang lumayan besar. Untuk mengetahui lebih rinci penggunaan tenaga kerja oleh masing-masing responden dapat dilihat pada tabel berikut :

\section{Tabel 8}

Responden Menurut Jumlah Tenaga Kerja (Orang)

\begin{tabular}{lrrr}
\hline \multicolumn{1}{c}{ Tenaga Kerja (Orang) } & Jumlah Responden & Persentase (\%) \\
\hline & 2 & 7 & 46,67 \\
& 3 & 5 & 33,33 \\
total & 4 & 3 & 20 \\
Rata-rata Tenaga kerja & & $\mathbf{1 5}$ & $\mathbf{1 0 0}$ \\
Sumberang & & $\mathbf{2}$ orang \\
\hline
\end{tabular}

Sumber : data olahan

Tabel 8 diatas, dapat dijelaskan bahwa responden yang menggunakan tenaga kerja sebanyak 2 orang berjumlah 7 orang responden atau sebesar 46,67 persen, jumlah responden yang menggunakan tenaga kerja sebanyak 3 orang berjumlah 5 orang atau sebesar 33,33 persen, dan responden yang menggunakan tenaga kerja sebanyak 4 orang berjumlah 3 orang atau sebesar 20 persen. Dari tabel diatas dapat disimpulkan bahwa rata-rata pengunaan tenaga pada industry kerupuk ikan ini sebesar 2 orang tenaga kerja.

\section{Responden Menurut Jumlah Produksi}

Maju mundurnya suatu industri tergantung pada jumlah produksi yang dihasilkan, yang pada akhirnya akan meningkatkan pendapatan pengusaha. Jumlah produk yang dihasilkan mencerminkan produktivitas, efisiensi dan kualitas dari pihak yang menghasilkan. Untuk mengetahui jumlah produksi kerupuk ikan pada masing-masing responden dapat dilihat pada tabel berikut :

Tabel 9

Responden Menurut Jumlah Produksi Kerupuk Ikan (Kg/Bulan)

\begin{tabular}{lrr}
\hline \multicolumn{1}{c}{ Jumlah Produksi Kerupuk Ikan (Kg / bulan) } & Jumlah (orang) & Persentase (\%) \\
\hline 30 & 4 & 26,67 \\
40 & & 60 \\
$>50$ & 2 & 13,33 \\
Jumlah & & $\mathbf{1 0 0}$ \\
Rata-rata Produksi & $\mathbf{1 5}$ & $\mathbf{3 9 , 2} \mathbf{~ k g} / \mathbf{b u l a n}$ \\
\hline
\end{tabular}

Sumber: data olahan 
Tabel 9. diatas, dapat diketahui bahwa responden dengan jumlah produksi kerupuk ikan sebesar $>50$ kilogram per bulan berjumlah 2 orang atau sebesar 13,33 persen, kemudian responden dengan jumlah produksi sebesar 30 kilogram per bulan berjumlah 4 orang atau sebesar 26,67 persen. Dan jumlah produksi terbanyak yaitu sebesar 40 kilogram perbulan berjumlah 9 orang atau sebesar 60 persen. Rata-rata produksi perbulan setiap pengrajin kerupuk ikan di Kelurahan Jelmu Kota Jambi yaitu sebesar 39,2 Kg/bulan.

\section{Responden Menurut Harga Jual Produksi}

Selain dipengaruhi oleh jumlah produksi, besarnya pendapatan bersih pengusaha industri kerupuk ikan dipengaruhi juga oleh harga kerupuk ikan itu sendiri. Tingkat harga pada tiap-tiap pengrajin kerupuk ikan berbeda-beda yaitu antara Rp. 35.000 sampai Rp. 40.000. Perbedaan jumlah biaya produksi yang dikeluarkan dalam proses produksi kerupuk ikan menyebabkan perbedaan harga kerupuk ikan yang dihasilkan. Untuk mengetahui harga kerupuk ikan pada setiap industri kerupuk ikan di Kelurahan Jelmu Kecamatan Pelayangan Kota Jambi dapat dilihat pada tabel berikut :

\section{Tabel 10}

\section{Responden Menurut Harga kerupuk ikan (Rupiah/kg)}

\begin{tabular}{|c|c|c|}
\hline Harga kerupuk ikan (Rupiah/kg) & Jumlah Responden & Persentase (\%) \\
\hline 35.000 & 7 & 46,67 \\
\hline 40.000 & 8 & 53,33 \\
\hline Jumlah & 15 & 100,00 \\
\hline Harga Rata-rata kerupuk ikan & & $37.666,67$ \\
\hline
\end{tabular}

Sumber : data olahan

Tabel 10 diatas, dapat dijelaskan bahwa responden yang menjual kerupuk ikan dengan harga Rp. 35.000 berjumlah 7 orang atau sebesar 46,67 persen, sedangkan responden yang menjual kacang goreng dengan harga Rp. 40.000 berjumlah 8 orang atau sebesar 53,33 persen. Hal ini sangat di pengaruhi oleh besarnya jumlah biaya produksi yang di keluarkan oleh pengrajin kerupuk ikan itu sendiri, seperti untuk pembelian ikan, tepung dan lainya serta biaya untuk upah tenaga kerja, hal inilah yang mebedakan harga pada tiap-tiap pengrajin. Adapun rata-rata harga dari setiap pengrajin kerupuk ikan di Kelurahan Jelmu yaitu Rp. 37.666,67.-

\section{Responden Menurut Biaya Produksi}

Biaya produksi yang dihitung dalam penelitian ini adalah seluruh biaya operasional yang dikeluarkan oleh setiap pengusaha Kerupuk ikan di Kelurahan Jelmu Kecamatan Pelayangan Kota Jambi dalam hitungan rupiah/bulan. Biaya produksi meliputi a) Bahan Baku: Ikan, Minyak tanah, Garam, Kayu bakar, Tepung sagu, Plastik, Telur, Lilin; b) Peralatan: Panci, Baskom, Papan Lindasan; dan c) Upah tenaga kerja

Tabel 11

\section{Perhitungan Biaya Produksi Pengrajin Kerupuk Ikan di Kelurahan Jelmu Kecamatan Pelayangan} Kota Jambi

\begin{tabular}{|c|c|c|c|c|}
\hline \multirow{2}{*}{ Responden } & \multicolumn{2}{|r|}{ Biaya Produksi } & \multirow{2}{*}{\multicolumn{2}{|c|}{ Total Biaya (TC) }} \\
\hline & Peralatan (FC) & Bahan baku (VC) Upah TK (VC) & & \\
\hline 1 & 12.500 & 200.000 & 540.000 & 752.500 \\
\hline 2 & 12.500 & 220.000 & 500.000 & 732.500 \\
\hline 3 & 12.500 & 350.000 & 625.000 & 987.500 \\
\hline 4 & 12.500 & 280.000 & 600.000 & 892.500 \\
\hline 5 & 12.500 & 200.000 & 740.000 & 952.500 \\
\hline 6 & 12.500 & 350.000 & 525.000 & 887.500 \\
\hline 7 & 12.500 & 250.000 & 450.000 & 712.500 \\
\hline 8 & 12.500 & 350.000 & 540.000 & 902.500 \\
\hline 9 & 12.500 & 270.000 & 510.000 & 892.500 \\
\hline 10 & 12.500 & 325.000 & 595.000 & 932.500 \\
\hline 11 & 12.500 & 250.000 & 635.000 & 897.500 \\
\hline 12 & 12.500 & 275.000 & 631.000 & 918.500 \\
\hline
\end{tabular}




\begin{tabular}{|c|c|c|c|c|c|}
\hline & 13 & 12.500 & 315.000 & 525.000 & 852.500 \\
\hline & 14 & 12.500 & 360.000 & 595.000 & 967.500 \\
\hline & 15 & 12.500 & 350.000 & 520.000 & 882.500 \\
\hline Rata-rata & & 12.500 & $289.666,67$ & $568.733,33$ & $877.566,67$ \\
\hline
\end{tabular}

Sumber : data olahan

Tabel 11. diatas, dapat diketahui bahwa jumlah responden yang mengeluarkan biaya produksi antara Rp. 712.500 - 987.504 perbulan. Dari tabel diatas dapat kita lihat rata-rata biaya produksi yang di keluarkan setiap pengusaha kerupuk ikan yaitu Rp. 877.566,67 perbulan. Berdasarkan upah tenaga kerja tiap bulan yang di keluarkan oleh pengusaha dapat kita lihat rata-rata upah tenaga kerja yang di keluarkan oleh tiaptiap pengusaha yaitu sebesar Rp. 8.531.000.-kemudian dari biaya rata-rata yang dikeluarkan oleh masingmasing pengusaha untuk pembelian bahan baku yaitu sebesar Rp. 4.345.00.- kemudian biaya yang dikeluarkan untuk pembelian peralatan setelah dihitung penyusutan selama 5 tahun pakai maka di peroleh biaya untuk pembelian peralatan perbulannya sebesar Rp. 12.500.- Kemampuan memproduksi baik secara kualitas setiap industri kerupuk ikan relatif berbeda, hal ini erat kaitannya dengna modal yang digunakan dari dan oleh sumber daya yang dimilikinya. Semakin besar jumlah modal yang dimiliki maka semakin besar pula jumlah produksinya, yang pada akhirnya akan meningkatkan pendapatan pengusaha kerupuk ikan. Serta besar kecilnya biaya produksi yang dikeluarkan oleh pengrajin di bedakan oleh besarnya biaya yang di keluarkan untuk membeli alat, bahan baku serta upah yang dikeluarkan oelh tiap-tiap pengrajin.

\section{Pendapatan Kotor}

Pendapatan kotor (TR) dari penjualan kerupuk ikan yang dimaksud dalam penelitian ini adalah hasil kali total produksi kerupuk ikan perbulan (Q) dengan harga $(\mathrm{P})$. Berdasarkan hasil penelitian dan perhitungan diketahui bahwa pendapatan kotor dari penjualan kerupuk ikan bervariasi, yaitu berkisar antara Rp. 700.000 - Rp. 1.999.999. Pendapatan kotor dari penjualan kerupuk ikan tertinggi (Rp.1.960.000) diperoleh 1 orang responden yaitu Anita sedangkan Hasanati dengan pendapatan Rp. 1.820.000.- sedangkan pendapatan kotor dari penjualan kerupuk ikan terendah (Rp. 1.050.000) diperoleh 1 orang responden yaitu Rina Aryani perbedaan pendapatan kotor dari penjualan kerupuk ikan masing-masing responden akan menyebabkan perbedaan pendapatan bersih yang akan diperoleh. Berikut ini akan ditampilkan tabel jumlah responden menurut pendapatan kotor dari penjualan kerupuk ikan yang diperoleh responden perbulan (Rupiah).

Tabel 12

Perhitungan Pendapatan Kotor Pengrajin Kerupuk Ikan di Kelurahan Jelmu

\begin{tabular}{|c|c|c|c|}
\hline Responden & Jumlah Produksi & Harga (Rp) & Pendapatan kotor (Rp) \\
\hline 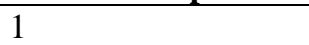 & 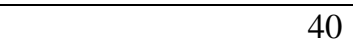 & 35.000 & 1.400 .000 \\
\hline 2 & 30 & 35.000 & 1.050 .000 \\
\hline 3 & 56 & 35.000 & 1.960 .000 \\
\hline 4 & 40 & 40.000 & 1.600 .000 \\
\hline 5 & 40 & 40.000 & 1.600 .000 \\
\hline 6 & 40 & 35.000 & 1.400 .000 \\
\hline 7 & 40 & 35.000 & 1.400 .000 \\
\hline 8 & 30 & 40.000 & 1.200 .000 \\
\hline 9 & 40 & 35.000 & 1.400 .000 \\
\hline 10 & 30 & 40.000 & 1.200 .000 \\
\hline 11 & 40 & 40.000 & 1.600 .000 \\
\hline 12 & 52 & 35.000 & 1.820 .000 \\
\hline 13 & 40 & 40.000 & 1.600 .000 \\
\hline 14 & 40 & 40.000 & 1.600 .000 \\
\hline 15 & 30 & 40.000 & 1.600 .000 \\
\hline Rata-rata & 35,47 & $37.66,67$ & $1.495 .333,3$ \\
\hline
\end{tabular}

Sumber : data olahan 
Berdasarkan uraian tabel perhitungan pendapatan kotor diatas dapat di hitung jumlah responden menurut pendapatan kotor dari penjualan kerupuk ikan sebagai berikut:

\section{Tabel 13}

Jumlah Responden Menurut Pendapatan Kotor dari Penjualan Kerupuk Ikan Perbulan (Rupiah)

\begin{tabular}{|c|c|c|}
\hline Pendapatan Kotor & Jumlah (orang) & Persentase $(\%)$ \\
\hline $1.050 .000-1.232 .000$ & 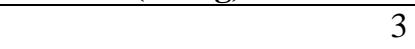 & 20 \\
\hline $1.232 .001-1.414 .001$ & 4 & 26,67 \\
\hline $1.414 .002-1.596 .002$ & 0 & 0 \\
\hline $1.596 .003-1.778 .003$ & 6 & 40 \\
\hline $1.778 .004-1.960 .004$ & 2 & 13,33 \\
\hline Total & 15 & 100 \\
\hline Rata-rata pendapatan kotor & & $1.495 .333,3$ \\
\hline
\end{tabular}

Sumber : data olahan

Tabel 13. diatas, diketahui bahwa responden dengan pendapatan kotor dari penjualan kerupuk ikan berkisar antara Rp. $1.050 .000-1.960 .000$ perbulan. Pengusaha kerupuk ikan dengan pendapatan berjumlah Rp. 1.050.000 - 1.960.000.- sebanyak 3 orang atau 20 persen. Dengan pendapatan Rp. 1.232.001 1.414.001.- sebanyak 4 orang atau 26,67 persen. Kemudian pengusaha kerupuk ikan dengan pendapatan kotor Rp. 1.596.003 - 1.778.003.- sebanyak 6 orang dan dengan pendapatan Rp. 1778.004 - 1.960.004.sebanyak 4 orang pengusaha. Adapun pendapatan rata-rata dari masing-masing pengusaha kerupuk ikan yaitu sebesar Rp.1.495.333,3.- pebulannya.

\section{Pendapatan Bersih}

Pendapatan bersih yang dimaksud adalah besarnya pendapatan kotor (penerimaan) yang diperoleh dari setiap pengrajin kerupuk ikan di Kelurahan Jelmu Kota Jambi perbulanya setelah dikurangi biaya produksi. Untuk mengetahui lebih jelas maka dapat kita lihat pada tabel Berikut ini:

\section{Tabel 14}

Perhitungan Pendapatan Usaha Pengrajin Kerupuk Ikan di Kelurahan Jelmu

\begin{tabular}{|c|c|c|c|c|c|c|}
\hline \multirow[b]{2}{*}{ Responden } & \multirow[b]{2}{*}{ Penerimaan (Rp) } & \multicolumn{4}{|c|}{ Biaya Produksi } & \multirow{2}{*}{$\begin{array}{l}\text { Pendapatan } \\
\text { Bersih } \\
(\mathrm{Rp})\end{array}$} \\
\hline & & $\begin{array}{l}\text { Peralatan } \\
\text { (FC) }\end{array}$ & $\begin{array}{l}\text { Bahan } \\
\text { (VC) }\end{array}$ & $\begin{array}{l}\text { Upah Tenaga } \\
\text { Kerja (VC) }\end{array}$ & $\begin{array}{l}\text { Total } \\
\text { (TC) }\end{array}$ & \\
\hline 1 & 1.400 .000 & 12.500 & 200.000 & 540.000 & 752.500 & 647.500 \\
\hline 2 & 1.050 .000 & 12.500 & 220.000 & 500.000 & 732.500 & 317.500 \\
\hline 3 & 1.960 .000 & 12.500 & 350.000 & 625.000 & 987.500 & 972.500 \\
\hline 4 & 1.600 .000 & 12.500 & 280.000 & 600.000 & 892.500 & 707.500 \\
\hline 5 & 1.600 .000 & 12.500 & 200.000 & 740.000 & 952.500 & 647.500 \\
\hline 6 & 1.400 .000 & 12.500 & 350.000 & 525.000 & 887.500 & 512.500 \\
\hline 7 & 1.400 .000 & 12.500 & 250.000 & 450.000 & 712.500 & 687.500 \\
\hline 8 & 1.200 .000 & 12.500 & 350.000 & 540.000 & 902.500 & 297.500 \\
\hline 9 & 1.400 .000 & 12.500 & 270.000 & 510.000 & 892.500 & 507.500 \\
\hline 10 & 1.200 .000 & 12.500 & 325.000 & 595.000 & 932.500 & 267.500 \\
\hline 11 & 1.600 .000 & 12.500 & 250.000 & 635.000 & 897.500 & 702.500 \\
\hline 12 & 1.820 .000 & 12.500 & 275.000 & 631.000 & 918.500 & 905.500 \\
\hline 13 & 1.600 .000 & 12.500 & 315.000 & 525.000 & 852.500 & 747.500 \\
\hline 14 & 1.600 .000 & 12.500 & 360.000 & 595.000 & 967.500 & 632.500 \\
\hline 15 & 1.600 .000 & 12.500 & 350.000 & 520.000 & 882.500 & 717.500 \\
\hline Rata-rata & $1.495 .333,3$ & 12.500 & $289.666,67$ & $568.733,33$ & $877.566,67$ & $618.033,33$ \\
\hline
\end{tabular}

Sumber : data olahan

Berdasarkan uraian tabel perhitungan pendapatan bersih diatas dapat di hitung jumlah responden menurut pendapatan pendapatan bersih dari penjualan kerupuk ikan sebagai berikut: 
Tabel 15

Jumlah Responden Menurut Pendapatan Bersih dari Penjualan Kerupuk ikan Per Bulan (Rupiah)

\begin{tabular}{|c|c|c|}
\hline Kelompok Pendapatan usaha (Rp) & Jumlah (orang) & \\
\hline $267.500-408.500$ & 3 & 20 \\
\hline $408.501-549.501$ & 2 & 13,33 \\
\hline $549.502-690.502$ & 4 & 26,67 \\
\hline $690.503-831.503$ & 4 & 26,67 \\
\hline $831.504-972.504$ & 2 & 13,33 \\
\hline Total & 15 & 100 \\
\hline Rata-rata Pendapatan Usaha & & $618.033,33$ \\
\hline
\end{tabular}

Sumber : data olahan

Berdasarkan Tabel 15 diatas, dapat di jelaskan tingkat pendapatan pengrajin kerupuk ikan di Kelurahan Jelmu sangat bervariasi berkisar antara Rp. 267.500 - 408.500.- dengan rata-rata pendapatan usaha pengusaha kerupuk ikan perbulan adalah sebesar Rp. 618.033,33.-

\section{Pendapatan Keluarga}

Pendapatan keluarga yang dimaksud dalam penelitian ini adalah seluruh pendapatan yang diperoleh oleh setiap anggota keluarga dari para pengerajin kerupuk ikan setiap bulannya. Besar kecilnya pendapatan keluarga dari pengerajin kerupuk ikan di Kelurahan Jelmu sangat bergantung antara lain pada anggota keluarga yang bekerja maka diharapkan pendapatan keluarga akan semakin besar. Gambaran mengenai besarnya pendapatan keluarga pengerajin kerupuk ikan di Kelurahan Jelmu Kota Jambi dapat dilihat pada tabel berikut ini:

Tabel 16

Jumlah dan Persentase Responden Berdasarkan Pendapatan Keluarga Perbulan (Rupiah)

\begin{tabular}{lr}
\hline \multicolumn{1}{c}{ Responden } & Pendapatan Keluarga (Rp) \\
\hline 1 & 700.000 \\
2 & 665.000 \\
3 & 1.556 .000 \\
4 & 790.000 \\
5 & 830.000 \\
6 & 1.050 .000 \\
7 & 770.000 \\
8 & 985.000 \\
9 & 850.000 \\
10 & 675.000 \\
11 & 1.060 .000 \\
12 & 1.115 .000 \\
13 & 945.000 \\
15 & 678.000 \\
Rata-rata pendapatan keluarga & 1.225 .000 \\
\hline
\end{tabular}

Sumber : data olahan

Tabel 16. diatas, dijelaskan tingkat pendapatan keluarga pengrajin kerupuk ikan di Kelurahan Jelmu sangat bervariasi berkisar antara Rp. 620.000 - 1.500 .000 dengan pendapatan keluarga perbulan rata-rata sebesar Rp.926.266,67.-

\section{Kontribusi Pendapatan Pengrajin Kerupuk Ikan Terhadap Pendapatan Keluarga}

Pada bagian ini akan di jelaskan mengenai besarnya proporsi dari sumbangan pendapatan usaha pengrajin kerupuk ikan terhadap keluarga. Besarnya kontribusi ini di peroleh dari persentase perbandingan antara pendapatan usaha pengrajin kerupuk ikan dengan pendapatan keluarga. Besar kecilnya kontribusi pendapatan usaha pengrajin kerupuk ikan terhadap pendapatan keluarga akan sangat tergantung pada besarnya pendapatan usaha dari pengrajin kerupuk. dapat dilihat pada tabel berikut ini: 


\section{Tabel 17}

Perhitungan Kontribusi Pendapatan Usaha Pengrajin Kerupuk Ikan di Kelurahan Jelmu Kecamatan Pelayangan Kota Jambi

\begin{tabular}{lrrr}
\hline Responden & Pendapatan Usaha (Rp) & Pendapatan Keluarga (Rp) & Kontribusi (\%) \\
\hline 1 & 647.500 & 700.000 & 94,89 \\
2 & 317.500 & 665.000 & 49,62 \\
3 & 972.500 & 1.556 .000 & 63,30 \\
4 & 707.500 & 790.000 & 91,13 \\
5 & 647.500 & 830.000 & 79,52 \\
6 & 512.500 & 1.050 .000 & 50,00 \\
7 & 687.500 & 770.000 & 90,91 \\
8 & 297.500 & 985.000 & 31,47 \\
9 & 507.500 & 850.000 & 61,18 \\
10 & 267.500 & 675.000 & 41,48 \\
11 & 702.500 & 1.060 .000 & 67,45 \\
12 & 905.500 & 1.115 .000 & 81,97 \\
13 & 747.500 & 945.000 & 80,42 \\
14 & 632.500 & 678.000 & 95,13 \\
15 & 717.500 & 1.225 .000 & 59,59 \\
Rata-rata & $\mathbf{6 1 8 . 0 3 3 , 3 3}$ & $\mathbf{9 2 6 . 2 6 6 , 6 7}$ & $\mathbf{6 7 , 7 6}$ \\
\hline
\end{tabular}

Sumber : data olahan

Berdasarkan tabel 17. diatas, dapat dilihat bahwa kontribusi pendapatan usaha kerajinan kerupuk ikan terhadap pendapatan keluarga berkisar antara 30,20 - 93,29 persen. Dari tabel diatas dapat juga kita lihat kontribusi rata-rata dari setiap pengusaha kerupuk ikan di Kelurahan Jelmu Kecamatan Pelayangan Kota Jambi yaitu 67,76 persen.Ini menunjukan bahwa pendapatan usaha pengrajin kerupuk ikan memberikan kontribusi yang cukup besar terhadap pendapatan keluarga.

\section{SIMPULAN}

1. Sebagian besar responden memiliki biaya produksi berkisar antara Rp. 712.500 - 987.504.- perbulanya. Dengan biaya produksi rata-rata perbulannya yaitu sebesar Rp. 877.566,67.- per bulanya.

2. Sebagian besar responden memiliki penerimaan atau pendapatan kotor berkisar antara Rp. 1.050.000 1.960.004.- perbulan. Dengan pendapatan kotor rata-rata sebesar Rp. 1.495.333,3 perbulan. Penerimaan tersebut merupakan penjualan yang belum dikurangi modal dan biaya produksi.

3. Pendapatan bersih pengusaha kerupuk ikan berkisar antara Rp. 267.500 - 972.504.- perbulan. dengan rata-rata pendapatan usaha masing-masing pengusaha antara Rp. 618.033,33.- per bulan.

4. Kontribusi pendapatan usaha pengusaha kerupuk ikan terhadap pendapatan keluarga berkisar antara 41,48 - 95,13 persen perbulan. Dengan rata-rata kontribusi perbulannya untuk masing-masing responden sebesar 67,76 persen perbulannya.

\section{DAFTAR PUSTAKA}

Alhudhori, M., 2017, Pengaruh IPM, PDRB, dan Jumlah Pengangguran Terhadap Penduduk Miskin di Provinsi Jambi, Ekonomis: Journal Economics and Business, 1(1), 113-124

Anonim. 2001. Indikator Industri Besar Dan Sedang Kota Jambi Tahun 2001. Badan Pusat Statistik (BPS), Jambi.

Adisetiawan, R., dan Hasminidiarty, 2011, Analisis Pengaruh Variabel-variabel Makroekonomi dan Mikroekonomi Terhadap Risiko Investasi Saham, Jurnal Ekonomi, 16(2), 159-174

Adisetiawan, R., 2012. Analisis Pengaruh Kinerja Keuangan dalam Memprediksi Pertumbuhan Laba, Jurnal Aplikasi Manajemen, 10(3), 669-681

Adisetiawan, R., 2013, Kajian Persepsi Pemilik Usaha Kecil dan Menengah (UKM) Terhadap Laporan Keuangan, Jurnal Ilmiah Universitas Batanghari Jambi, 13(4), 162-173

Fahmi, Irham. 2013, Pengantar Manajemen Keuangan, Teori Soal dan Jawab, Bandung: Alfabeta

Hikam Lazuardy, 2016, Analisis Pengukuran Kinerja Keuangan Dengan Model Altman Z-Score dan Tobin's Q. Studi Kasus Pada Perusahaan Sektor Makanan Dan Minuman Di BEI Periode 2010-2014. 